\title{
PESQUISAR PARA EDUCAR?
}

\author{
Maria Imaculada de Fátima Freitas* \\ Maria Auxiliadora Condova Christofaro**
}

Gostaríamos de agradecer o convite para participar do Encontro Internacional "Pesquisa em Enfermagem: uma questão de saúde" e cumprimentar a Escola de Enfermagem da Universidade de São Paulo pelos seus 50 anos de vida. Queremos também pedir desculpas pela ausência da Professora Maria Auxiliadora Cordova Christófaro, ocupada com os afazeres da direção da ABEn-Central.

Decidimos redigir juntas este trabalho, considerando as discussóes que viemos fazendo sobre as questões da Universidade em geral e da Saúde em particular, quando sempre prevaleceu a preocupação em analisar as interrelações entre esses dois campos de ação do homem e o potencial de transformação do trabalho que as pessoas executam nas mais diversas áreas da produção do conhecimento e da formação dos recursos humanos. Estamos aqui diante de pessoas que, possivelmente, comungam conosco essa preocupação com um processo que pode levar à afirmação de algumas certezas e à descoberta de muitas dúvidas.

Falamos em dúvida, filha da curiosidade, que nasce exatamente porque nos relacionamos uns com os outros, e é desse processo coletivo é que, ao longo da história da humanidade, chegamos a desenvolver posturas, procedimentos, conhecimentos, perguntas e vazios, que se acumulam, se negam e reaparecem, dando-nos a real medida do infinito do conhecimento. $E$ nessas permanentes idas e vindas da humanidade que nós podemos conceber que o exercício da educação e da investigação no homem não se dá no espaço de um momento, ou como um ato logicamente definido ou pré-definido, e sim uma dinâmica imensurável de afirmações e negações das coisas e das significações das coisas.

Estas considerações iniciais têm pertinência neste momento pois a primeira atitude que nos ocorreu ao buscar trabalhar o tema proposto foi nos colocarmos de frente com a questão tal como está posta no título desta mesa-redonda: "Pesquisar para Educar". A preposição "para" dá um destino, define uma finalidade. A pesquisa com finalidade de educar? Estamos diante de uma assertiva ou de uma provocação, e conseqüentemente, de um convite à reflexão? Optamos por esta segunda compreensão.

Para facilitar que a nossa fala provoque a reflexão dos parceiros, trabalharemos com a questào Pesquisa e Educação, com o que já é conhecido e com

- Enfermeira. Doutora em Ciencias da Educação. Professor Adjunto da Escola de Enfermagem da UFMG.

** Enfermeira. Professor Assistente da Escola de Enfermagem da UFMG. Presidente da Associação Brasileira de Enfermagem. 
aquilo que está "magicamente" posto, de tal sorte que possamos desnudar o "mágico" que está em nós, o nosso engajamento e as nossas expectativas.

Sabemos que pesquisa e educação têm caminhado pari passu com o desenvolvimento da sociedade humana. Se assim não fosse, como entender que o homem, ao se descobrir em grupos geograficameinte distantes uns dos outros, para cuja sobrevivência são necessárias ações que demandam forças além da sua própria, pensa e constrói a roda, assegurando com isto a possibilitade de aproximação e troca e também a realização de trabalhos específicos como o de arar a terra? Alguém identifica nesse proceder do homem o que é a educação e o que é a pesquisa? O fato é que, nesse "comportamento humano", fica inscrita a sua sobrevivência em determinado momento e abre-se um leque de sobrevida e de alternativas futuras das quais esse homem não teve toda a consciência ao pensar e fabricar a roda.

Se, por um lado, não conseguimos identificar uma separação nítida entre pesquisar e educar nos vários momentos do desenvolvimento da sociedade, por outro, sabemos que no próprio processo desse desenvolvimento, ambos, a pesquisa e éducação, não são compreendidas como tendo um objeto único: o conhecimento. Ao contrário, a educação vem referida historicamente a determinados eixos ou tendências tidos como da sua natureza e a pesquisa aparece em outro cenário, conformando-se como parte de um mundo contiguo à educação, até mesmo proximo, porém diferente.

Se considerarmos os vários entendimentos existentes sobre educação e pesquisa, com certeza identificaremos tendências que as vêem como partes de um todo, outras, como partes que se somam ao sodo, e outras, ainda, como um todo em si.

Para além dessas concepções, vamos encontrar aquelas que as entendem como movimentos recíprocos de interação do todo com as partes, bem como movimentos de contraposição das partes entre si. Neste grupo estão aquelas tendências que afirmam que, independentemente das contradiçőes inerente a todo processo de formação e desenvolvimento social, há um movimento de afirmação e de negação permanente, o que engendra novos e diferentes processos.

A nossa escolha é de nos incluirmos neste último grupo, pois acreditamos que a cristalização do significado e dos conceitos das coisas nos levará a um "beco sem saída ", onde o único recurso seria o de cairmos obssessivamente na busca de definições acabadas, úteis e indispensáveis à sociedade, mas que, se buscadas isoladamente, encerram o conhecimento num contexto intransitivo, fazendo desaparecer o encanto do "novo" gestado a partir da negação do "antigo". Dessa forma, entendemos que o processo de descoberta do novo (investigação) através de procedimentos contextualizados e coletivos (educação) é a síntese de múltiplas determinações e ambos, processo e procedimentos, são imanentes à natureza humana.

Mas o fato de serem da natureza humana não quer dizer que sejam únicos, unos, homogêneos. A incorporação de um conhecimento novo não resulta necessariamente num sêr educado. Tampouco o fato de um indivíduo ou um grupo não ter um determinado conhecimento significa que este conhecimento não existe $\mathrm{e}$ sobre esse ponto de vista, queremos registrar dois postulados fundamentais relativos à pesquisa e à educação. Primeiro é de que não é no nível do indivíduo que se realiza o processo da educação e da investigação. O seguindo refere-se ao fato 
de que ambos, educação e pesquisa, não são instâncias a serem quantificadas ("mais educado, menos educado", "esta pesquisa é mais pesquisa que aquela outra ") e sim qualificadas. Os elementos de qualificação dessas instâncias dizem respeito à sua pertinência social, à capacidade do des-cobrir contido nelas, à possibilidade de serem incorporadas às práticas e às necessidades do aqui e agora da vida dos indivíduos e da coletividade, e sim, muito mais do que isto, a capacidade de indicar o provável, o vir a ser.

Queremos dizer que estas questões não estão aqui tratadas de forma exaustiva, tampouco contemplam todas as vertentes e abordagens que podem ser tomadas para compreendê-las. Os aspectos aqui tratados são recentes, vêm como resultado de nossas dúvidas. No entanto, aqui estão colocados porque acreditamos que a Universidade, a Escola, os profissionais de saúde e dentre eles, nós, enfermeiras, devem estabelecer com a sociedade uma aliança para buscar na educação e na investigação as dúvidas que orientam a crítica às nossas certezas, reorientando a nossa prática. Parafraseando Wilson Luiz Sanvito (1), sabemos que a ciência na nossa época está sacralizada e sua filha dileta, a tecnologia, está mitologizada. Entretanto, sabemos que o mundo não pode ser explicado pura e simplesmente pelos axiomas e postulados científicos, pelo uso ou não de tecnologias, por procedimentos mais ou menos "educados".

\section{REFERÊNCIA BIBLIOGRÁFICA}

SANVITO, W. L. Em busca do intercâmbio cientffico. In MEDINA, C. O novo pacto da ciencia : a crise dos paradigmas. São Paulo, ECA/USP, 1990. p.45. 